\title{
A Formulation to Eradicate Bureacratic Corruption in Indonesia: A Model of Ethics in Public Administration
}

\author{
Saiful Deni \\ Department of Administration Science, Muhammadiyah University of North Maluku, Ternate City, Indonesia
}

Email address:

Ipuldeni.ummu@gmail.com

\section{To cite this article:}

Saiful Deni. A Formulation to Eradicate Bureacratic Corruption in Indonesia: A Model of Ethics in Public Administration. Social Sciences. Vol. 5, No. 2, 2016, pp. 21-25. doi: 10.11648/j.ss.20160502.13

Received: March 24, 2016; Accepted: April 5, 2016; Published: May 6, 2016

\begin{abstract}
This study tried to reveal ways to reduce bureaucratic corruption that occurred in the institutions of government agencies. Bureaucratic corruption phenomenon almost spreaded in various state structures. Most studies on bureaucratic corruption had not been able to devise means and strategies that were best in handling and reducing corruption. The results of this study also tried to offer the formulation of a new formula to eradicate corruption in Indonesia Bureaucracy through Public Administration Ethical Approach. The method used in this study described the use of literature review, which deepens various concepts of corruption eradication of bureaucracy in the literature data, read, record and process materials that formulated the theory of a formula that was expected to be the first clue to the bureaucracy of corruption eradication in Indonesia.Several theories were used in formulating the theory, among others: Teleological, Deontological; and Virtue Ethics in the Ethics Administration. Teleological theory emphasized the good and bad aspects as well as the causes and consequences of bureaucratic corruption. Deontological theory emphasized the right or bad, either an action does not depend on the outcome rather than the compulsory nature of the act itself. Deontological ethics assume that acts of corruption are things of any bad consequences. The theory of virtue ethics emphasized "good character" as evidenced by integrity. Virtue ethics could be understood from the order from the soul to do something well. The results of this study concluded that the reduction of bureaucratic corruption ideally starts from the strengthening of ethical values that are useful to distinguish between the good and the bad; better consistency of actions; morals for the government; promoting honesty and fairness; both administrative and legal actions across the government bureaucracy in Indonesia. Similarly, some of the options in reducing bureaucratic corruption are namely: needs for greater control over participatory community social dynamics; and criticism and supervision of bureaucratic behavior. The study concludes that, the corruption of the bureaucracy can be reduced if the integrity of state officials, virtue and conscience of the government to end the bad deeds is achieved.
\end{abstract}

Keywords: Deontologies, Teleologies, Virtue Ethics, Bureaucratic Corruption, Administration Ethics

\section{Introduction}

In the Indonesian context, the phenomenon of the abuse of power that developed in colonial era showed in the form of arbitrariness and corruption (for example, the elimination of tax money) by the village chief and regent. It was influenced by the culture as a regent with the bureaucracy that is not paid enough to make ends meet, then the government will levy illegally from the public what is not obtained legally (Onghokham, 1980).

The Old Order era (1957-1965) that began with the democratic system guided by the President also raised many issues important for social and economic conditions of concern to the people of Indonesia. Under the regime of Soekarno government occured financial abuse, abuse of bureaucratic, and judicial cooperation among politicians and military officials with the patronage system (Johnston, 2005). The Old Order era caused corruption, endangered territorial integrity. Social justice had not been achieved and economic problems unsolved and many of the expectations generated by the revolution did not achieve their intended purpose. Corruption in Indonesia at the time was almost entirely dominated the life of the nation and the state (Alatas, 1999). Leadership change still leaved the corrupt behavior.

In the New Order regime (1965-1998) forces that rely on 
the power of the state budget, the nationalization of the country, bribes and short positions and bureaucratic costs exists. Corruption in the New Order era was authoritarianism that illustrated the participation of government and state political power held by the elite (Kang, 2004). The resultant regulations under the New Order was given to businessmen as a source of abuse of power. Predatory behavior being carried out systematically through the power of the state bureaucracy (Bhargava and Bolongaita, 2004), through the behavior of individuals and groups of economists who have the power to control the positions of the state bureaucracy (Hadiz and Dhakidae, 2005). Corruption in this era also increased to corruption behavior which continued during the reform era that still exists in government.

The author therefore examines the problem of corruption as a first step in which the power of the bureaucracy worsens due to damage to mental and behavioral bureaucracy. This study intends to formulate an ethics approach model to the eradication of bureaucratic corruption in public administration.

The Statement of The Problem

How to formulate the bureaucracy in Indonesia Corruption in Public Administration Ethics approach?

\section{Methodology}

This research design was literature review based study. Literature research is a series of activities related to the data collection methods of literature, reading, recording and processing literature materials (Zed, 2008: 3). Sources of data in the research included: books, journals, articles, periodicals, government documents, sources on the Internet, and various types of reports and documents (either unpublished or already published (Zed, 2008; Eller and Bearfield 2008; George, 2008; Miller and Yang, 2008).

\subsection{Theories / Conepts}

\subsubsection{Theory of Public Administration Ethics}

In public administration ethics theory, the researcher used three approaches: (1) the theory of teleology from the perspective of public administration ethics, (2) the theory of deontology in the perspective of public administration ethics, and (3) the theory of virtue ethics (ethics of virtue). The third ethical theory was used to view and understanding the ethics officer or behavioral phenomena of public authorities in the running of power in Indonesia.

\subsubsection{Theory of Teleology in Public Administration Ethics}

Etymologically derived from the teleological ethical theory "Telos" which means the end. Teleological ethical theory colud also be referred to as a consequentialist ethical theory judging "that either bad or wrong really an act could be seen from the results or consequences". An act is morally good or right if the result is good (Rasuanto, 2005).In the context of acts of corruption for this theory could be understood that the "act of corruption was wrong because it impacts or have adverse consequences to the state, communities and individuals". So the implications for teleological ethical theories directly related to the purposes and objectives that determines whether something can be beneficial to the interests of bureaucrats, public or otherwise adversely affects the individual and the institution. So teleological ethical theories focus on the Consequences.

In the context of public administration ethics, teleological emphasize on all frameworks and activities can be valuable and has implications for public policy purposes and the best service. Even discretion satisfies citizens. Ethical theory teleology is a set of human values extensive, a passion which is based on the morality of the ruler, organizational power, pleasure, knowledge, virtue, love, freedom, and beauty, which desire must have positive consequences on a decision rationality and organizationally (Pops, 2001).

\subsection{Theory of Deontology in Public Administration Ethics}

Etymologically the word deontology comes from the word "Deon" which means the obligation. Said deontological in moral philosophy known as the name of one of a large group of normative ethical theory. Deontological theory can also be referred to as a non-consequentialist ethical theory which holds that "one really good bad or an action does not depend on the result rather than the obligatory nature of the action itself" (Rasuanto, 2005). For deontological ethical theory considers that "the act of corruption is a bad deed at any cost". Other experts such as Immanuel Kant, John Rawls and Frankena support multiple streams associated with the ethics flow like, deontology. Implications of deontology within the framework of that in carrying out the tasks of government is a very important theory to guide the bureaucrats to implement the rules on bureaucratic institutions.

Deontological ethical theory (Rasuanto, 2005) assumes that the value of the rights (the right) has priority over a good value (the good). Deontology flow that emphasizes the obligations and motives underlying a decision taken by officials or any act of bureaucracy and bureaucrats in lands by ethical values. So focus on the deontological ethical obligations and the principles to be followed. Standards applied in the theory of deontology always associated with the correct actions or a moral obligation based on moral truth in carrying out the task's state.

In Kantian theory, "deontology" oriented to the moral basis or something fundamental in doing good actions (Coop, 2006). The choice of the action based on moral authorities, otherwise considered dangerous in MEET public and private needs. Meanwhile, According to Frederickson (in Chandler, 2001) that "the legitimacy of the regime of power is a function of honesty and fairness applicable to the level of good deeds or virtues in administrative and legal. On the basis of insularity subordinate or corrupt practices can reduce honesty, justice, and virtue, weaken the legitimacy of the regime. Deontological ethical problems that can be identified associated with honesty, fairness, and public officials of high virtue of the application of ethical principles in public administration. 


\subsection{Theory of Virtue Ethics in Public Administration Ethics}

The theory of virtue ethics is a criticism or contradiction on the previous theory, the theory of deontology and teleology. The theory of virtue ethics holds that a good or evil, right or wrong does not depend on the result or consequence (teleology), or of the obligations or principles to be adhered to (deontology), but the theory of virtue ethics emphasizes the "good character" as evidenced by integrity (Bowman, 2003). Virtue ethics can be understood from the order form in the soul to do something well. This view gives the meaning that we are obliged to do good, not because there is a push to get something, or follow certain principles or certain obligations, but something good works depends on the integrity, kindness, or the conscience of the authorities in carrying out the task's state.

According to Hart (2001) the categories are intended to form: (1) the cardinal virtue (main virtues), which outlines (A) prudence (wisdom), justice (justice), fortitude (grit / toughness), Temperance (simplicity), (2) excellence of moral character (good moral character), (3) virtues and the active life (virtues and zest for life), (4) moral intentionality (moral goodness), (5) moral reinforcement and moral refreshment (the strengthening of moral and moral refreshment), (6) living the best life (living well in finding a job).

The categories above are in the context and policy issues for administrators who face the modern organizations and the development of society in the contemporary age. The administrator should make a virtue as the main aspect of their character. Virtue ethics can be applied to the behavior of public officials in the organization's activities, and it serves as a guide to be followed. The choice for the authorities is based on the character, quality and the guarantee of the authorities to fight crime with the aim to follow virtue.

Virtue ethics theory in perspective normative ethics of public administration can be used to advocate the concept to a practical level. Started by identifying the concept for the public administrator to have consequences on professionalism. The idea of virtue (virtue) in the implementation of the government in power is the ultimate protection of public goods in the fight against acts of corruption (Cooper, 2001).

Virtue ethics can solve problems such as skills and learning to act right. Ethics for public officials may provide a way to become the foundation for the principles and rules. Virtue ethics is the main object of an evaluation of honesty and character in the governance of the forms of life that is more meaningful (Annas, 2006). This potential if done in earnest can generate concepts in an effort to avoid and prevent corruption in state losses. So the theory of virtue ethics focuses on integrity, virtue, and the conscience of the government to end the bad deeds, such as corruption and abuse of power in this country.

\section{Result and Discussion}

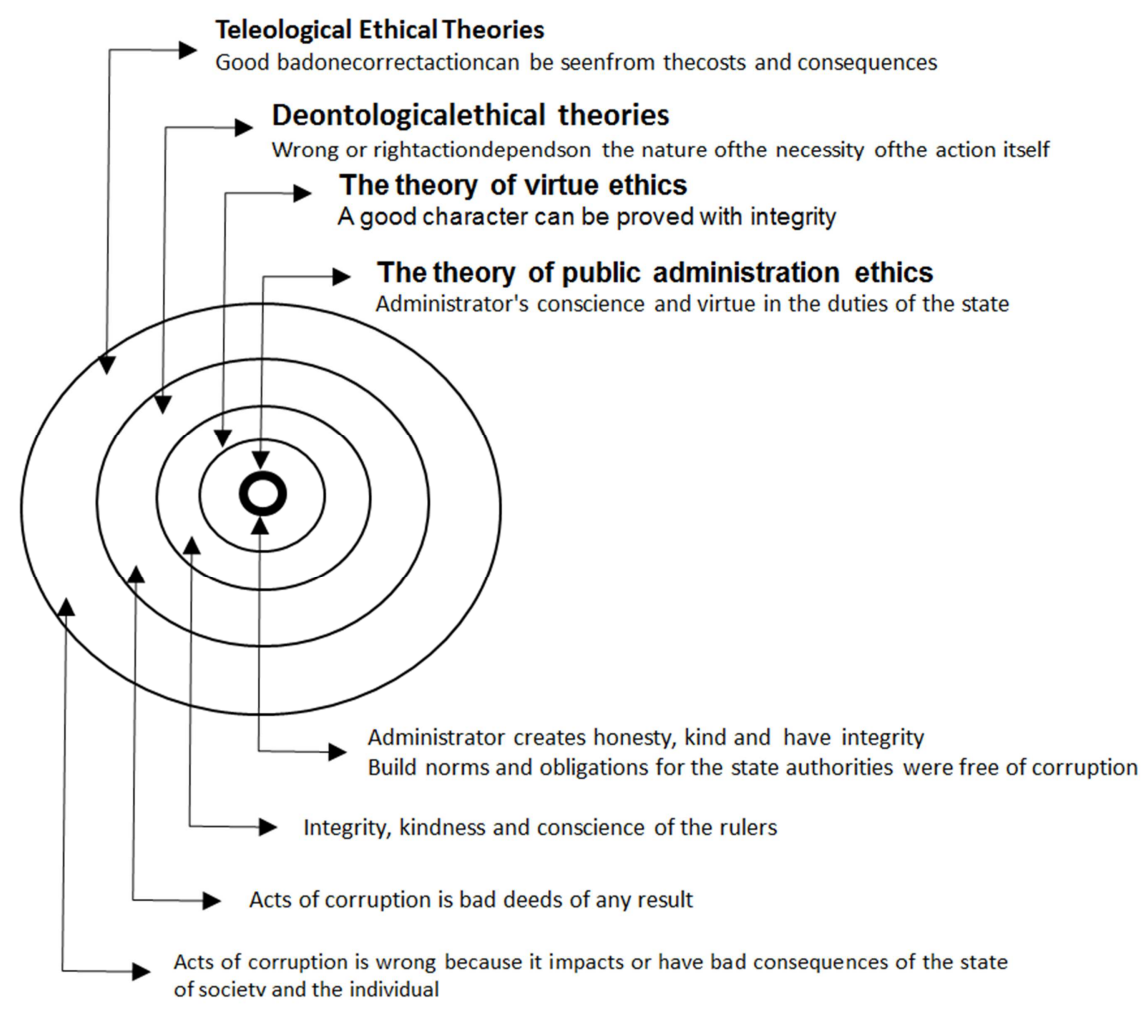

Source: Author

Figure 1. Formulation against Corruption Bureaucracy Reduction in Ethical Approach in Public Administration (The title should be framed better: A model of Ethics in Public Administration?). 
In understanding the consequentialist ethics (teleological) was as described in the previous theory that an activity is considered ethically correct depending on the utility or usability. In this case of corruption by bureaucrats was not based on ethical values useful. When utilitarianism becomes the base and on the same principle in action to determine which action is right or wrong. What to do in running the affairs of the bureaucracy. This point was reiterated that officials do not have to take the path and outside the procedures applicable law. What not to do. It has upheld a ban on any bureaucrats for not doing fraudulent practices that could undermine the work of the bureaucratic system. Another thing is that every bureaucrat should distinguish between right or wrong in the actions of individuals and rulers.

Every bureaucracy is always faced with a moral foundation or something fundamental in doing good deeds. Bureaucracy associated with the legitimacy of the officials who worked on aspects of honesty and justice, evidenced by the level of good deeds or virtues in the administration and law. Cheating from subordinate employees can damage the image of a high official. Corruption of employees or staff may reduce honesty, justice, and virtue, reduce and affect the legitimacy of the regime at the top level. This will cause adverse effects on the rules of fairness, justice, and public officials of high virtue of the application of ethical principles in public administration.

\subsection{The Morality of Bureaucracy Administrator}

Morality is very influential on the rules for the implementation of government functions and in particular have an interest to administrators. Influence in the context of public administration, among other things, first, Achieve the goal of public policy. The activities of government policy aim to uphold the law for political leadership. In addition, all actions or measures in order to improve the work ineffectively. This species has a reason to clarify the instruments in the form of rules, principles of rationality and efficiency in devoting a good criteria. Bureaucracy ideally works under the practice of public administration intends to emphasize the results and the interests that benefit the stakeholders of collective and not personal interests.

Second, the survival of the organization. Bureaucracy maintains a consequence of government decision-making in practice, so it can survive. Ethical attitude is to serve well to illustrate and maintain motivation in stabilizing requirements, see it as an urgent need to implement the process of governance and an end to the activities for policy purposes. The essence of State and Government to move and maintain the ethics of power. Not worth it if the opportunity and existence obtain the objectives of policies that do not benefit a feeling of power and guarantees the continuing influence of the ruling.

Third, participative society. One of the successes of the bureaucracy is the ability to design policies that can stimulate communication and participatory society. Bureaucracy as a major force and as a state actor must understand teleological ethics specifically for generating excitement and gain opportunities for public / community to debate, argue, and also modify for the sake of improvement and refinement. Certainly the use of teleological ethics is the principles infinite or rules that do not bring harm to the administrator.

\subsection{Virtue Ethics the Bureaucrats}

Authorities should be able to use the runway "virtue ethics" to avoid bad behavior in power (such action), because virtue ethics offer several categories of the rejection of the underlying bad acts or behavior of officials who abuse their authority. By virtue ethics is owned by a public authority, can avoid the challenges in dealing with personal conflict of interest or other state actors.

In the context and policy issues for administrators Indonesia, aims to boost the quality of public services in order to improve the capacity of modern organizations and the development of society in the contemporary age. The administrator must make a virtue as the main aspect of their character. virtue ethics can be applied to the behavior of public officials in the activities of the organization, and serves as a guide to follow. Options for the authority based on quality character and guarantees from the government to fight crime with the aim to follow virtue.

Virtue ethics can solve problems such as skills and learn to do right. Ethics bureaucracy can give best practical guidance to enforce the rules of correct principles. virtue ethics as an instrument to evaluate the honesty and character of the government of the shape of a more meaningful life. Potential ethical bureaucracy still requires earnest seriousness that it is becoming an ethical culture in an effort to avoid and prevent corruption in state losses. So the theory of virtue ethics focuses on integrity, virtue and the conscience of the rulers end the bad deeds, such as corruption and abuse of power in this country.

\section{Conclusion}

Consequentialist ethical theories (teleological) explain that acts of corruption by bureaucrats is not based on ethical values that are useful. The emphasis should be on what is the foundation and at the same time the principle in action to determine whether an act is right or wrong and rational choice of individuals who are always consistent in determining wrongdoing and right actions. This principle as an individual choice of the underlying activity is to act ethically, properly and well.

In theory of Kantian, "deontology" oriented to the moral basis or something fundamental in doing acts of good, moral for the authorities, such as the legitimacy of the regime of power are a function of honesty and fairness that has implications for the level of good deeds or virtues in administrative and legal. Deontology criticize that the acts of corruption can reduce honesty, justice, and virtue, undermined the legitimacy of a regime. Deontological ethical 
issues that can be identified is associated with honesty, justice, and virtue high public officials for the application of ethical principles in public administration.

Participatory Society is a strategy in the debate, opposing, and also modify the behavior that is good for the bureaucracy in Indonesia. The authorities should be able to use the runway "virtue ethics" to avoid any bad behavior in power (such actions), because virtue ethics offer several categories of underlying rejection of bad actions or behavior of officials who abuse their authority.

Ethics for bureaucratic officials may provide a way to become the foundation for the principles and rules, as an evaluation of honesty and character inpracticed governance to produce concepts in an effort to avoid and prevent a wide range of acts of corruption that cost the state in integrity, virtue, and the conscience of the authorities puts an end to the bad deeds, such as corruption and abuse of power in the country.

\section{Recomendation}

Ideally, reduction of bureaucratic corruption starts from the strengthening of ethical values that are useful. There needs to be an emphasis on the dividing line between good and bad for consistency. The spirit of moral deontology approach should ideally be the fundamental basis in undertaking good actions, moral for the authorities, promoting honesty and fairness, both administrative and legal actions through the government bureaucracy of Indonesia.

It is time to eradicate corruption patterns using dynamic, participatory society, social control, supervisión. Criticism of bureaucrats behavior are good for the bureaucracy in Indonesia. Officials can ideally avoid government bureaucrats from various bad behaviors in power (such actions), the behavior of officials who abuse their authority.

We recommend starting the process of eradicating corruption from the planting of the ethical values of the bureaucracy as a way to strengthen the foundation, evaluate the honesty and character of practiced government in earnest. Corruption can be reduced if there is an official state of integrity, virtue and conscience of the government to end the bad deeds.

\section{References}

[1] Annas, Julia, 2006. "Virtue Ethics", in Coop, David (ed) The Oxford Handbook of Ethical Theory. Oxford University Press, Inc. New York.
[2] Bhargava, V, and Bolongaita, E, 2004. Challenging Corruption in Asia: Case Studies and a Framework for Action, The World Bank, Washington, D. C.

[3] Bowman, J. S, 2003. "Virtue Ethics", in Rabin, Jack (ed), "Encyclopedia of Public Administration and Public Policy, Marcel Dekker, New York.

[4] Caiden, 2005. An Anatomy of Official Corruption, in Frederickson. George. H, and Ghere Richard K. (eds), Ethics in Public Management, M.E. Sharpe, New York.

[5] Coop, David, (ed), 2006. The Oxford Handbook of Ethical Theory. Oxford University Press, Inc. New York.

[6] Cooper, Terry L, (ed) 2001. The Emergence of Administrative Ethics as a Field of Study in the United State, in Handbook Of Administrative Ethics, Marcel Dekker. Inc., New York.

[7] Eller. Warren, and Dominic A. Bearfield, 2008. Writing a Literature Review: The Art of Scientific Literature, in Miller. J Gerald and Yang Kaifenf, (ed) 2008. Handbook of Research Methods in Public Administration, CRC Press, New York.

[8] Frederickson, H, George. 1993. Ethics and Public Administration, Publishers M.E. Sharpe, Inc. New York.

[9] Hadiz, Vedi. R, and Dhakidae, Daniel (ed), 2005. Social Science and Power in Indonesia, Equinox Publishing ISEASJakarta and Singapore.

[10] Hart, K, David, 2001. Administration and the Ethics of Virtue In All things, Choose First for Good Character and Then for Technical Expertise, in Cooper L, Terry (ed), Marcel Dekker Inc., New York.

[11] Kang, C. David, 2004. Crony Capitalism: Corruption and Development, United Kingdom, Cambridge University Press.

[12] Onghokham, 1983. Tradition and Corruption, in Lubis, Mochtar and Scott. C James, 1985. Anthology Corruption, First Edition, LP3ES, Jakarta.

[13] Pops, Gerald M., 2001. A Teleological Approach to Administrative Ethics, in Cooper, Terry L, (ed) 2001 "Handbook Of Administrative Ethics", Marcel Dekker. Inc., New York.

[14] Rasuanto, Bur, 2005. Social Justice: The views Deontological Rawls and Habermas, Two Theories of Modern Political Philosophy, Gramedia Pustaka Utama. Jakarta.

[15] Zed, Mustika, 2008. Research Methods Literature, Obor Indonesia, Jakarta. 